\title{
Physicochemical Characterization of Tropical Wines Produced in the Northeast of Brazil
}

\author{
L.L.A. Lima ${ }^{a}$ \\ Universidade Federal Rural \\ de Pernambuco \\ Universidade Federal Rural \\ de Pernambuco - UFRPE \\ Rua Dom Manoel de \\ Medeiros, s/n, Dois Irmãos \\ CEP: 52171-900 \\ G.E. Pereira \\ Embrapa Uva e \\ Vinho/Semi-árido - Rod. \\ BR $428 \mathrm{Km} \mathrm{151,} \mathrm{CP} 23$ \\ CEP. 56.302-970 \\ Petrolina \\ Brazil \\ Recife \\ Brazil
}

\author{
N.B. Guerra \\ Universidade Federal de \\ Pernambuco (UFPE-DN) \\ Campus Universitário \\ CEP. 50670-901 \\ Recife \\ Brazil
}

Keywords: tropical wines, polyphenols, organic acid

\begin{abstract}
Young varietal and experimental wines from Vitis vinifera L. - Petit Verdot and Tempranillo - cultivated in a tropical semiarid region (Northeast Brazil) were characterized with regard to their phenols and organic acids. The wine was evaluated using spectrophotometry and high performance liquid chromatography to determine total polyphenols, total anthocyanins and organic acids. The Petit Verdot wines showed highest polyphenols and anthocyanins concentrations. However, the Tempranillo wine showed highest acidity. Both cultivars produce typical tropical red wines in the Northeast of Brazil.
\end{abstract}

\section{INTRODUCTION}

The production and wine quality depend on many factors, like edafoclimate conditions. The lower-middle region of the São Francisco river Valley, in the Northeast of Brazil, is located between the $8^{\circ}$ and $9^{\circ}$ parallels of the Southern hemisphere, characterized by a tropical semiarid climate. Grape production can be scaled throughout the year and one vine can produce two or three times per year (Pereira et al., 2007; Tonietto and Carbonneau, 2004). This characteristic is the case because region has high solar radiation, temperatures and water for irrigation, that can vary according to the month in the year, providing typical variations in the phenolic and organic acid composition of the grapes and consequently in the wines (Lima, 2010; Rastija et al., 2008; Pereira et al., 2005). Moreover the phenolic compounds are found to be associated with biochemical and pharmacological effects that are beneficial to human health (Guerrero et al., 2009; Kumar et al., 2009). And the acid composition found association to aging wines.

This evidence motivated this study, which aims to evaluate the organic acid and phenolic compositions of tropical wines produced in the Northeast of Brazil.

\section{MATERIALS AND METHODS}

\section{Winemaking}

Young monovarietal and experimental wines were produced with $V$. viniferas $\mathrm{L}$. cv. Petit Verdot and Tempranillo, cultivated in the Casa Nova/BA, Northeast of Brazil, which harvests were carried out in July 2008. Eighty kg of grapes from each variety were vinified on a semi-industrial scale, followed by manual bottling (Peynaud, 1997). The determinations of the polyphenols and organic acids were performed after 3 months of storage in 750-ml bottles with agglomerated cork stoppers in a wine cellar heated at $18 \pm$ $1{ }^{\circ} \mathrm{C}$ and with an average relative humidity of $60 \%$.

\footnotetext{
a lucianalima.ufrpe@gmail.com
} 


\section{Determination of the Polyphenols and Organic Acids of Tropical Wines}

Polyphenolic: the index at $280 \mathrm{~nm}\left(\mathrm{I}_{280 \mathrm{~nm}}\right)$ was found by reading the absorbance of wines diluted in water at $2 \%$, at $280 \mathrm{~nm}$ using quartz cuvettes and a Varian 50 Bio UV/Vis spectrophotometer (Harbertson and Spayd, 2006).

Total anthocyanins: this analysis was done using the spectrophotometer method of differential $\mathrm{pH}$ by changing the chromophoric structure of anthocyanins in acidic medium according to OIV (Office International de la Vigne et du Vin, 1990).

Organic acids: organic acids (tartaric, malic, lactic, citric and succinic) were identified and quantified in the Ultimate 3000 Dionex ${ }^{\circledR}$ liquid chromatograph with an Acclaim ${ }^{\circledR} 120$ Dionex C-18 analytical column $(250 \mathrm{~mm} \times 4.6 \mathrm{~mm}, 5 \mu \mathrm{m})$, wavelength $210 \mathrm{~nm}$. The mobile phase was prepared by mixing phosphoric acid $(0,10 \%)$ and acetonitril $(0,12 \%)$ in ultra-pure water (Milli-Q, Millipore $\left.{ }^{\mathbb{B}}\right)$. The compounds were quantified in an analytical curve with concentrations varying from 0.01 to $1.0 \mathrm{mg} \mathrm{L}^{-1}$ by external pattern (Lima et al., 2010).

\section{Statistical Analysis}

The results were obtained in triplicate and submitted to ANOVA and Duncan Test for comparison among averages $(p<0.05)$ and analysis of the principal components (APC). All statistical analysis was performed using the Statistics for Windows 7® Software.

\section{RESULTS AND DISCUSSION}

These results showed the interaction of the vine and edaphoclimate conditions produces typical variation in the physicochemical composition.

In the Table 1, the results confirmed the influence of grape variety on the polyphenol amounts in wines and showed the highest levels of total polyphenols and anthocyanin concentration in the Petit Verdot wines.

Moreover, it confirmed that tartaric and lactic acids are the main organic acids in the tropical red wines (Table 1). The wines showed the similar concentrations of tartaric, lactic and succinic acids. The results were similar to those reports by Zheng et al. (2009) - lactic acid, 3,4 g. $\mathrm{L}^{-1}$ and tartaric acid, 2,5 g. $\mathrm{L}^{-1}$ - for Australian red wines, and by Peres et al. (2009), in Brazilian red wines (harvests 2000 - 2002).

Considering the performance of malolactic fermentation and the little resistance to oxidation of malic acid, the absence of this acid was expected independently of the variety. Accretia also explains the fact of the malic decreasing during maturation of the grapes especially in warm climate (Rizzon and Sganzerla, 2007).

\section{Multivariate Statistical Analysis}

Separation of the tropical red wines was performed using values of total polyphenols $\left(\mathrm{I}_{280 \mathrm{~nm}}\right)$, total anthocyanins and organic acid composition. The first two principal components extracted $99.99 \%$ of the total variance, which the first principal component (PC1) represents $99.87 \%$, was dominated by total polyphenols, total anthocyanins, tartaric, lactic acid and succinic acids and total organic acids (Fig. 1).

As can be seen in Figure 1, the Petit Verdot wines on the left of the graphic (in the negative side of PC1) were characterized by total anthocyanins, total polyphenols and lactic acid, and Tempranillo wines on the right of the graphic (in the positive side of PC1) were characterized by tartaric and succinic acids and total organic acids, as can be confirmed by values in the Table 1 .

\section{CONCLUSIONS}

Variations in the phenolic and organic acid compositions of red tropical wines, elaborated from different grape cultivars, were found. However, the polyphenol levels and anthocyanins concentration remained higher than those reported for wines produced in temperate regions and similar composition to organic acid was observed. 


\section{ACKNOWLEDGEMENTS}

The authors thanks the Conselho Nacional de Desenvolvimento Científico e Tecnológico (CNPq), Fundação de Amparo à Pesquisa de Pernambuco (Facepe) for their financial support, and the Miolo Wine Group for the grapes.

\section{Literature Cited}

Guerrero, R.F., Liazid, A., Palma, M., Puertas, B., González-Barrio, R., Gil-Izquierdo, A., García-Barroso, C. and Cantos-Villar, E. 2009. Phenolic characterisation of red grapes autochthonous to Andalusia. Food Chemistry 112:949-955.

Harbertson, J. and Spayd, S. 2006. Measuring phenolics in the winery. American Journal of Enological and Viticultural 57:280-288.

Kumar, A., Malik, A.K. and Tewary, D.K 2009. A new method for determination of myricetin and quercetin using solid phase microextraction-high performance liquid chromatography-ultra violet/visible system in grapes, vegetables and red wines samples. Analytical Chimica Acta 631:177-181.

Lima, L.L.A. Caracterização e estabilização dos vimhos elaborados no Vale do Submédio São Francisco. 2010. 139 p. Tese (Doutorado em Ciência dos Alimentos) - Centro de Ciências da Saúde, Departamento de Nutrição, Universidade Federal de Pernambuco, Recife.

Lima, L.L.A., Schuler, A., Guerra, N.B., Pereira, G.E., Lima, T.L.A. and Rocha, H. 2010. Otimização e validação de método para determinação de ácidos orgânicos em vinhos por cromatografia líquida de alta eficiência. Química Nova (33) 5:1186-1189.

Pereira, G.E., Gaudillere, J.-P., Leeuwen, C.V., Hildert, G., Lavialle, O., Maucourt, M., Deborde, C., Moing, A. and Rolin, D.H. 2005. NMR metabolite fingerprints of grape berry: comparison of vintage and soil effects in Bordeaux grapevine growing areas. Analytica Chimica Acta, www.elsevier.com/locate/aca

Pereira, G.E., Soares, J.M., Guerra, C.C., Alencar, Y.C.L., Lira, M.M.P., Lima, M.V.O. and Santos, J. 2007. Caractérisation de vins rouges tropicaux produits au Nord-Est du Brésil. In: Proceedings of the $59^{\text {th }}$ German Viticulture Congress Wine in Motion. Stuttgart, Alemanha.

Peres, R.G., Moraes, E.P., Micke, G.A., Tonin, F.G., Tavares, M.F.M. and RodriguezAmaya, D.B. Rapid method for the determination of organic acids in wine by capillary eletrophoresis with indirect UV detection. Food Control (20) 548-552.

Peynaud, E. 1997. Connaissance et travail du vin. Paris :Editora Dunod, 341p.

Rastija, V., Srecnik, G. and Saric, M.-M. 2008. Polyphenolic composition of Croatian wines with different geographical origins. Food Chemistry, Doi: 101016/i-foodchem.

Rizzon, L.A. and Sganzerla, V.M.A. 2007. Ácidos tartárico e málico no mosto de uva em Bento Gonçalves-RS. Ciência Rural (37)3:911.

Tonietto, J. and Carbonneau, A. 2004. A multicriteria climatic classification system for grape-growing regions worldwide. Agricultural and Forest Meteorology 124:81-97.

Zheng, Y.J., Duan, Y.T., Zhang, Y.F., Pan, G.H., Li, J.M. and Huang, W.D. 2009. Determination of organic acids in red wine and must on only one RP-LC-Colimn directly after sample dilution and filtration. Chromatographia, Doi: 10.1365/s10337009-1085-0. 


\section{$\underline{\text { Tables }}$}

Table 1. Characterization of polyphenols and organic acids in tropical red wines.

\begin{tabular}{l|ccccccc}
\hline Variety & POL $^{\mathrm{a}}$ & $\mathrm{ANT}^{\mathrm{b}}$ & \multicolumn{5}{c}{ Organic Acid $\left(\mathrm{g} . \mathrm{L}^{-1}\right)$} \\
\cline { 5 - 8 } & $\left(\mathrm{I}_{280 \mathrm{~nm}}\right)$ & $\left({\left.\mathrm{mg} . \mathrm{L}^{-1}\right)}^{n}\right.$ & Tartaric & Malic & Lactic & Citric & Succinc \\
\hline Petit Verdot & $70,4^{\mathrm{a}} \pm 0,04$ & $508,0^{\mathrm{a}}$ & $2,63^{\mathrm{b}}$ & ND & $7,30^{\mathrm{a}}$ & ND & $1,40^{\mathrm{b}}$ \\
& & $\pm 0,86$ & $\pm 0,04$ & & $\pm 0,01$ & & $\pm 0,20$ \\
Tempranillo & $69,1^{\mathrm{b}}$ & $356,6^{\mathrm{b}}$ & $2,78^{\mathrm{a}}$ & ND & $7,02^{\mathrm{b}}$ & ND & $1,78^{\mathrm{a}}$ \\
& $\pm 0,36$ & $\pm 0,72$ & $\pm 0,01$ & & $\pm 0,0,1$ & & $\pm 0,01$ \\
\hline
\end{tabular}

a: polyphenols total índex of $280 \mathrm{~nm}$; b: total anthocyanins. Average followed of different letter significant difference according to the test of Duncan $(\mathrm{p}<0,05)$.

\section{Figures}

(A)

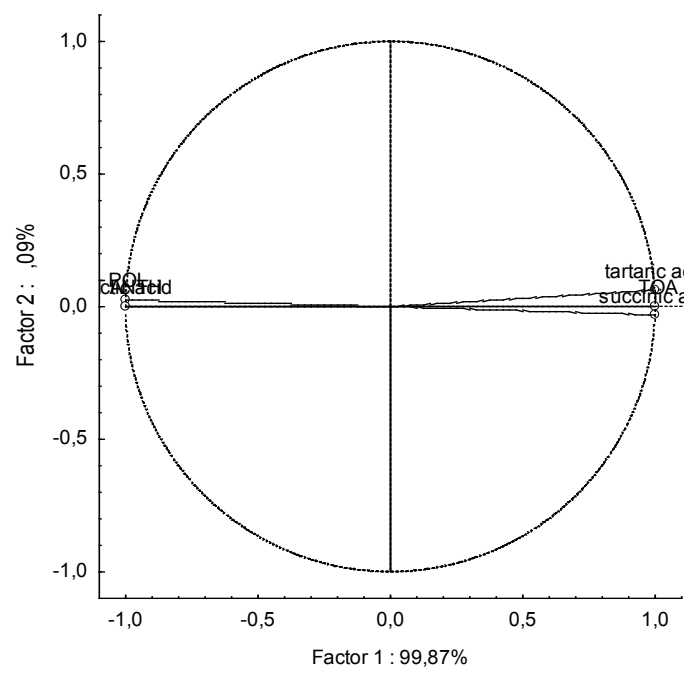

(B)

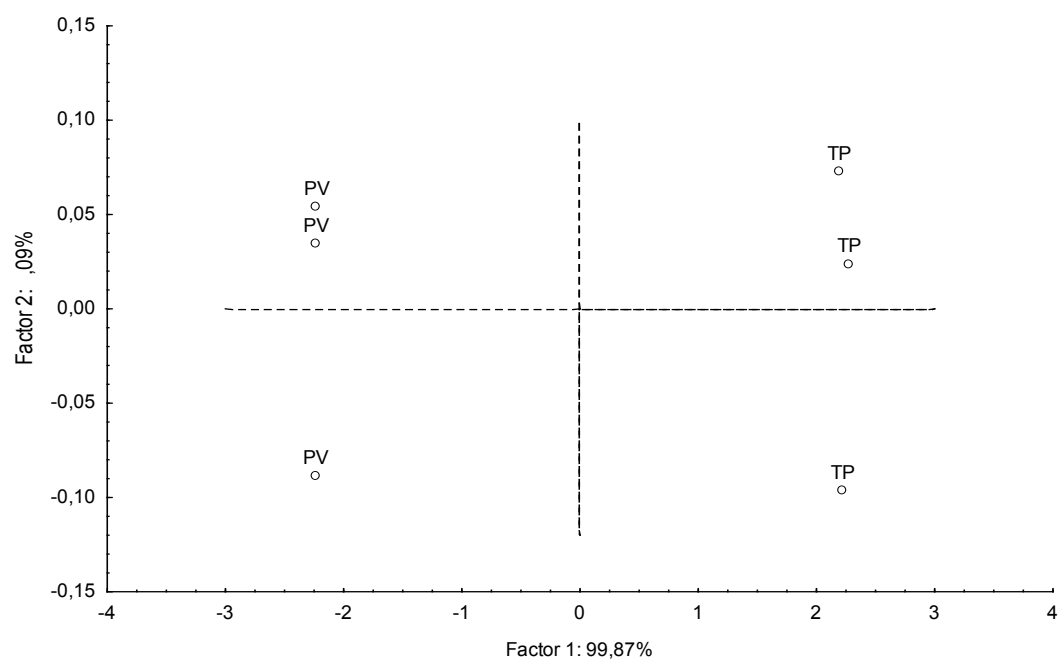

Fig. 1. Variable contribution (A) and the distribution of the red wines (B) (PV= Petit Verdot e TP $=$ Tempranillo) in two dimension with the coordinates system defined the first and second principal component. 